ISSN 0258-7122 (Print), 2408-8293 (Online)

Bangladesh J. Agril. Res. 41(2): 221-234, June 2016

\title{
INFLUENCE OF SUCROSE AND ALUMINIUM SULPHATE VASE LIFE OF CUT HIPPEASTRUM FLOWER (Hippeastrum hybridum Hort.) AS INFLUENCED
}

\author{
M. K. JAMIL ${ }^{1}$, M. M. RAHMAN ${ }^{2}$, M. M. HOSSAIN ${ }^{2}$ \\ M. T. HOSSAIN ${ }^{3}$ AND A. J. M. S. KARIM ${ }^{4}$
}

\begin{abstract}
An experiment with Hippeastrum flower (Hippeastrum hybridum Hort.) cv. 'Apple Blossom' comprising three sucrose concentrations viz. 0 (control), 2 and $4 \%$ and five aluminium sulphate concentrations viz. 0 (control), 0.25, 0.50, 0.75 and $1.0 \mathrm{mM}$ at the Horticulture Laboratory of Bangabandhu Sheikh Mujibur Rahman Agricultural University, Bangladesh during the period from April 01 to April 30, 2009. The experiment was laid out in a Completely Randomized Design (CRD) with three replications. Sucrose, aluminium sulphate and their combinations had significant influence on most of the parameters studied. Transpiration loss and water uptake ratio decreased significantly with the increased sugar levels and aluminium sulphate upto $0.75 \mathrm{mM}$ beyond which they were increased. Transpiration loss and water uptake ratio was found minimum in the vase solution containing $4 \%$ sucrose $(0.78)$ and $0.75 \mathrm{mM}$ aluminium sulphate $(0.80)$, which ultimately resulted in an enhanced vase life (9.2 days for sucrose and 9.11 days for aluminium sulphate) of cut Hippeastrum flower. A linear relationship between water uptake and vase life of flowers was found $(y=0.056 x+5.791)$. Sucrose $4 \%$ and aluminium sulphate $0.75 \mathrm{mM}$ in combination gave maximum total water uptake, maximum days to onset of deterioration, the highest average fresh weight of single scape at $6^{\text {th }}$ and $10^{\text {th }}$ day after setting the trial. Transpiration loss and solution uptake ratio was found maximum in the combination of $4 \%$ sucrose and $0.75 \mathrm{mM}$ aluminium sulphate (0.48) with the longest vase life of 10.33 days of cut Hippeastrum flower cv. 'Apple Blossom'.
\end{abstract}

Keywords: Sucrose, aluminium sulphate, transpiration loss, vase life, Hippeastrum flower and Hippeastrum hybridum Hort.

\section{Introduction}

Hippeastrum (Hippeastrum hybridum Hort.), a member of Amaryllidaceae family is one of the finest flowering bulbous plants. The genus Hippeastrum consists of 75 species and more than 300 cultivars (Bhattacharjee and De, 2010). The flowers are typically arranged in umbels at the apex of leafless flowering stem, called a

${ }^{1}$ Senior Scientific Officer, Biotechnology Division, Bangladesh Agricultural Research Institute (BARI), Gazipur, ${ }^{2}$ Professor, Department of Horticulture, Bangabandhu Sheikh Mujibur Rahman Agricultural University (BSMRAU), ${ }^{3}$ Professor, Department of Crop Botany, BSMRAU, ${ }^{4}$ Professor, Department of Soil Science, BSMRAU, Salna, Gazipur, Bangladesh. 
scape. The flowers are spectacular having various shades of bright colour and wide range of variation exists in cultivars developed by hybridization. It is a well known pot and garden plants. It is also popular as cut flowers because of their large size, attractive colour, and good keeping quality. The flowers can be used to beautify the garden and decorate the verandah and also for great demand as cut flowers in floriculture trade (Datta et al., 2008).

Vase life of the Hippeastrum flower varies from 10-15 days depending on the number of flower per scape, environment and change of water. Sucrose and aluminium sulphate are used as preservatives in vase solution for prolonging the vase life of cut flowers (Gowada, 1990; Gowada and Murthy, 1994; Gowada and Gowada, 1990). Sucrose is the most widely used floral preservatives that maintain the pool of dry matter and respirable substrates in floral petals and exogenous sucrose replaces the depleted endogenous carbohydrates utilized during post harvest life of cut flowers (De and Bhattacharjee, 2006). Treatment with sucrose promoted unfolding petals, suppresses the decrease in fresh dry weight of cut flowers and inhibition on the occurrence of petals senescence (Ichimura et al., 2003).

Aluminium sulphate, a germicide, has been found to reduce petal $\mathrm{pH}$ to stabilize the anthocyanin of petals to acidify the holding solution, to reduce bacterial and fungal growth (Halevy and Mayak, 1981) and it is reported that aluminium sulphate extended vase life and improved water relation of cut rose flowers by antimicrobial effect (Ichimura and Ueyama, 1998). Farhat et al. (2014) reported that sucrose in combination with aluminium sulphate is better for improving vase life in rose. Several attempts have also been made to study the effect of some germicide and sugars on longevity and keeping quality to tube rose (Pathak et al., 1979). There has been reported that the Hippeastrum cut flower remains fresh for a longer period if it is kept in 3 percent sugar solution (Jana, 1979).

Despite the importance of Hippeastrum as well known cut flower, very few research works have been done on vase life of cut Hippeastrum scapes using sucrose and aluminium sulphate. The present investigation was therefore, undertaken to find out the optimum concentration of sucrose and aluminium sulphate for enhancing vase life and keeping quality of cut Hippeastrum flower.

\section{Materials and Method}

The experiment was conducted at the Horticulture laboratory of Bangabandhu Sheikh Mujibur Rahman Agricultural University (BSMRAU), Salna, Gazipur during 01 April to 30 April, 2009 to observe the effect of different concentrations of sucrose and aluminium sulphate on post harvest physiology of Hippeastum flower cv. Apple Blossom in vase under normal room temperature $\left(30^{\circ} \mathrm{C} \pm 2^{0} \mathrm{C}\right)$. The experiment was laid out in a Completely Randomized Design (CRD) with 
three replications. There were 15 treatment combinations comprising three concentrations of sucrose viz. $S_{0}=0 \%$ (control), $S_{1}=2 \%$ and $S_{2}=4 \%$ and five concentrations of aluminium sulphate viz. $\mathrm{A}_{0}=0 \%$ (control), $\mathrm{A}_{1}=0.25 \mathrm{mM}, \mathrm{A}_{2}$ $=0.50 \mathrm{mM}, \mathrm{A}_{3}=0.75 \mathrm{mM}$ and $\mathrm{A}_{4}=1.0 \mathrm{mM}$.

Forty five conical flasks $(500 \mathrm{ml}$ each) were filled with $300 \mathrm{ml}$ distilled water for both sucrose $(0,2$ and $4 \%)$ and different concentration of aluminium sulphate $(0$, $0.25,0.50,0.75$ and $1.0 \mathrm{mM}$ ) on respective conical flask and dissolved it by hand shaking. The plants of Hippeastrum cv. Apple Blossom were grown in the Horticulture Research Field of BSMRAU following the recommended package of production techniques. Hippeastrum floral scapes were harvested when the buds were fully elongated but not full open. The floral scapes were harvested early in the morning and were immediately placed in water. During harvesting, the scapes were cut horizontally in uniform length of $30 \mathrm{~cm}$ by sharp knife. Then the floral scapes were trimmed by about $2 \mathrm{~cm}$ under water again prior to place them in holding solution After harvesting, the scapes were carried out to the Horticulture laboratory and fresh weight was measured. Two floral scapes were used for each treatment consisting of a $500 \mathrm{ml}$ conical flask containing $300 \mathrm{ml}$ vase solution of given concentrations. The conical flasks were kept at room temperature of $30^{\circ} \mathrm{C} \pm 2^{0} \mathrm{C}$ with $65-80 \%$ relative humidity and adequate aeration. Data were recorded on every day based on the following parameters. Water uptake, transpiration loss of water and fresh weight was determined on alternate days.

a) Water uptake (g): The difference in weight between consecutive measurements of the conical flask + solution (without floral scape) represented the water uptake.

b) Transpiration loss of water (g): The difference in weight between consecutive measurements of the conical flask + solution + floral scape represented the transpiration loss of water.

c) Fresh weight of floral scape: The difference between the weight of conical flask + solution + floral scape and the weight of conical flask + solution represented the fresh weight of scape on that particular day.

d) Days taken to deterioration started: Days counted when the petals of the flowers started to dry.

e) Vase life (days): Wilting or fading of 50 percent of the flowers per scape was considered the end of the vase life of the floral scape.

All the recorded data were statistically analyzed through partitioning the total variance with the help of computer based MSTAT C Program. The difference between treatments means were compared by Duncan's Multiple Range Test (DMRT) (Gomez and Gomez, 1984). 


\section{Results and Discussion}

\section{A. Effect of sucrose Water uptake}

Total water uptake for a period of 10 days by the floral scape differed significantly due to sucrose levels (Table 1).The scape held in 4\% sucrose had the maximum water uptake $(57.08 \mathrm{~g})$ closely followed by the scape held in $2 \%$ sucrose and the scapes held in control had the minimum water uptake. Sugars play an important role in flower development, either as an energy source for respiration or as osmotically active substances, which aid in maintaining the turgidity of the expanding corollas. Sucrose improves water absorption from the vase solution which made a better water balance by maintaining turgidity and flower freshness (Reddy and Singh, 1997) and saves from early wilting resulting in enhanced vase life. This result is in agreement with the findings of Shobha and Gowda (1994) in calendula; Reddy et al. (1994) in gladiolus and Singh et al. (1994) in tuberose. The minimum water uptake of $45.10 \mathrm{~g}$ by the scape was recorded in control (without sucrose).

\section{Transpiration loss of water}

Water loss from the flower tissue by transpiration during the experimental period was influenced significantly by sucrose (Table 1). The scape held in solution without sucrose, with lower water uptake, recorded the highest water loss at 10 days $(60.46 \mathrm{~g})$ and those held in solution with $4 \%$ sucrose recorded the lowest water loss at 10 days $(42.27 \mathrm{~g})$. This might be due to the fact that sugar helped reduce moisture stress in cut Hippeastrum flowers by affecting stomatal closure, preventing water loss due to transpiration. The findings of the experiment corroborate the results of Khondakar and Mozumder (1985) in tuberose and Gowda (1986) in China aster.

\section{Transpiration loss and water uptake ratio}

The ratio of transpiration loss and water uptake is an indication of water balance in the flower scape. The transpiration loss and water uptake ratio was affected significantly by sucrose (Table 1). The ratio was found the highest (1.36) for the scape held in distilled water only (control) and it was the lowest $(0.78)$ for the scape held in vase solution with $4 \%$ sucrose. The lowest transpiration loss and water uptake ratio was found in sucrose solution because it increased water uptake and decreased water loss due to transpiration by regulating stomatal opening. This is in agreement with Gupta et al. (1994) who reported that $4 \%$ sucrose solution significantly reduced the ratio in gladiolus cut flowers.

\section{Days to onset of deterioration}

Days to onset of deterioration was not significantly influenced by sucrose level (Table 1). However, the longest duration to onset of deterioration (7.9 days) was 
observed in floral scape which holds $4 \%$ sucrose solution followed by $2 \%$ sucrose solution. The earliest deterioration (5.7 days) of floral scape was commenced in control. The onset of deterioration started when turgor of cut flowers was reduced by water deficit. This is in agreement with Khondakar and Mozumder (1985) who reported that the tuberose cut flowers retained their freshness for longer periods when higher concentrations of sucrose $(3 \%)$ were used. The treatment was also effective in retarding the abscission rate of the petals of the flowers.

\section{Vase life}

The vase life of the floral scape was affected significantly by sucrose levels (Table 1). The floral scape placed in $4 \%$ sucrose lasted for 9.2 days, while those in solution without sucrose lasted for only 7.00 days. The extended vase life might be due to water balance in cut Hippeastrum flowers as affected by sucrose in vase solution. Sugar also serves as a building block needed for the growth processes associated with flower opening and provides sufficient intercellular carbohydrate reserves to ensure an optimum vase life. These results are in agreement with previous workers who reported that sucrose was better than distilled water for preserving cut flowers of gladiolus cv. Priscilla and Moana (Garibaldi and Dembrogio, 1989). Treatment with 6\% sucrose maintained vase life of gladiolus for up to 11 days, which was better than that of distilled water was also reported by Anserwadekar and Patil (1986).

Table1. Main effect of sucrose on postharvest physiology and quality of Hippeastrum flower

\begin{tabular}{|c|c|c|c|c|c|}
\hline $\begin{array}{l}\text { Treatment } \\
\text { (Sucrose) }\end{array}$ & $\begin{array}{c}\text { Total water } \\
\text { uptake in } 10 \\
\text { days(g/scape) }\end{array}$ & $\begin{array}{l}\text { Transpiration } \\
\text { loss in } 10 \text { days } \\
\text { (g/scape) }\end{array}$ & $\begin{array}{l}\text { Transpiration } \\
\text { loss and water } \\
\text { uptake ratio }\end{array}$ & $\begin{array}{l}\text { Days to onset } \\
\text { of } \\
\text { deterioration }\end{array}$ & $\begin{array}{l}\text { Vase } \\
\text { life } \\
\text { (days) }\end{array}$ \\
\hline $\mathrm{S}_{0}($ Control $)$ & $45.10 \mathrm{~b}$ & $60.46 \mathrm{a}$ & $1.36 \mathrm{a}$ & 5.7 & $7.0 \mathrm{~b}$ \\
\hline$S_{1}(2 \%)$ & $48.25 \mathrm{ab}$ & $49.72 \mathrm{~b}$ & $1.05 \mathrm{~b}$ & 6.4 & $8.2 \mathrm{~b}$ \\
\hline $\mathrm{S}_{2}(4 \%)$ & $57.08 \mathrm{a}$ & $42.27 \mathrm{~b}$ & $0.78 \quad \mathrm{~b}$ & 7.9 & $9.2 \mathrm{a}$ \\
\hline $\begin{array}{l}\text { Level of } \\
\text { significance }\end{array}$ & $* *$ & $* *$ & $* *$ & $\mathrm{~ns}$ & $* *$ \\
\hline $\mathrm{CV}(\%)$ & 5.11 & 4.54 & 7.57 & 16.53 & 14.54 \\
\hline
\end{tabular}

Means in the same column followed by different letters are significantly different by DMRT. ** indicates significant at $1 \%$ level and 'ns' indicates non-significant

\section{B. Effect of aluminium sulphate \\ Water uptake}

Different levels of aluminium sulphate influenced significantly on water uptake of the floral scape (Table 2). The scapes held in $0.75 \mathrm{mM} \mathrm{Al}_{2}\left(\mathrm{SO}_{4}\right)_{3}$ had the 
highest water uptake $(61.90 \mathrm{~g})$, while those held in a solution without $\mathrm{Al}_{2}\left(\mathrm{SO}_{4}\right)_{3}$ (control) had the minimum water uptake $(41.18 \mathrm{~g})$. At higher conc. of aluminium sulphate $(1.0 \mathrm{mM})$, water uptake declined due to phyto toxicity in vase solution which causes chlorophyll degradation, chlorophyll fluorescence and increase in membrane permeability. Water absorbed by cut flowers is inversely related to the degree of vascular blockage. Since $\mathrm{Al}_{2}\left(\mathrm{SO}_{4}\right)_{3}$ acts as a germicide, thereby encouraging continuous water transport through the cut stem by inhibiting the vascular blockage and delaying the increase in membrane permeability. This corroborates the result of Shobha and Gowda (1994) in cut calendula flowers.

\section{Transpiration loss of water}

In case of $\mathrm{Al}_{2}\left(\mathrm{SO}_{4}\right)_{3}$, the maximum water loss $(55.56 \mathrm{~g})$ was observed in the scapes which held in solution without $\mathrm{Al}_{2}\left(\mathrm{SO}_{4}\right)_{3}$ and the minimum water loss $(47.11 \mathrm{~g})$ were found in $0.75 \mathrm{mM} \mathrm{Al} 2\left(\mathrm{SO}_{4}\right)_{3}$ solution (Table 2). The results are in close conformity with the findings of Shobha and Gowda (1994), who reported that the transpiration loss in cut calendula flowers was affected by accumulation of $\mathrm{Al}_{2}\left(\mathrm{SO}_{4}\right)_{3}$ both in the transpiring tissue and water content.

\section{Transpiration loss and water uptake ratio}

Transpiration loss and water uptake ratio (1.36) was found the highest from the scapes held in solution without aluminium sulphate (Table 2). Addition of $\mathrm{Al}_{2}\left(\mathrm{SO}_{4}\right)_{3}$ reduced the ratio either by improving the water uptake or reducing the water loss by transpiration, thus improving the water balance in the tissue. The ratio was found the lowest $(0.80)$ from the scape held in solution containing 0.75 $\mathrm{mM} \mathrm{Al}_{2}\left(\mathrm{SO}_{4}\right)_{3}$.

\section{Days to onset of deterioration}

Days to onset of deterioration of Hippeastrum cut flower was significantly influenced by different levels of $\mathrm{Al}_{2}\left(\mathrm{SO}_{4}\right)_{3}$ (Table 2). Flowers on scapes took the maximum days (7.4) for starting the deterioration at $0.75 \mathrm{mM} \mathrm{Al} 2\left(\mathrm{SO}_{4}\right)_{3}$ which was closely followed by $(7.1$ days $)$ at $1.0 \mathrm{mM} \mathrm{Al} 2\left(\mathrm{SO}_{4}\right)_{3}$. The minimum days (5.9) for deterioration of flowers were starting in control. One of the major requirements for an increased vase life i.e. delays in deterioration of cut flowers is that water uptake should not be hindered. Some workers reported that stem blockage is the major cause of water deficit and wilting of cut flowers (Rogers, 1973). Since $\mathrm{Al}_{2}\left(\mathrm{SO}_{4}\right)_{3}$ increases the water uptake, it might act to inhibit vascular blockage by suppressing microbial growth.

\section{Vase life}

$\mathrm{Al}_{2}\left(\mathrm{SO}_{4}\right)_{3}$ had no significant effect on vase life of Hippeastrum cut flowers (Table 2). However, the floral scape held in $0.75 \mathrm{mM} \mathrm{Al}{ }_{2}\left(\mathrm{SO}_{4}\right)_{3}$ had the 
maximum vase life (9.11 days), which was closely followed by 8.67 days at 1.0 $\mathrm{mM} \mathrm{Al}\left(\mathrm{SO}_{4}\right)_{3}$ solution and 7.78 days at $0.50 \mathrm{mM} \mathrm{Al}\left(\mathrm{SO}_{4}\right)_{3}$. The minimum vase life (7 days) for the scape was found in distilled water. The extension of vase life by $\mathrm{Al}_{2}\left(\mathrm{SO}_{4}\right)_{3}$ as observed in the present investigation, accords with previous results obtained in narcissus flowers (Goszczynska et al., 1989) and tuberose (Gowda, 1990). Aluminium sulphate acts as a germicide, and improves water uptake by cut calendula (Shobha and Gowda, 1994) and gladiolus (Gowda and Murthy, 1994) and thereby maintains the fresh weight. It is possible that $\mathrm{Al}_{2}\left(\mathrm{SO}_{4}\right)_{3}$ delays senescence of Hippeastrum flowers by increasing water uptake and maintaining a higher fresh weight, leading to enhanced vase life.

Table 2. Main effect of aluminium sulphate on postharvest physiology and quality of Hippeastrum flower

\begin{tabular}{l|l|l|l|l|c}
\hline $\begin{array}{c}\text { Treatment } \\
\left(\mathrm{Al}_{2}\left(\mathrm{SO}_{4}\right)_{3} \text { in }\right. \\
\mathrm{mM})\end{array}$ & $\begin{array}{c}\text { Total water } \\
\text { uptake in 10 } \\
\text { days(g/scape })\end{array}$ & $\begin{array}{c}\text { Transpiration } \\
\text { loss in 10 days } \\
\text { (g/scape) }\end{array}$ & $\begin{array}{c}\text { Transpiration } \\
\text { loss and water } \\
\text { uptake ratio }\end{array}$ & $\begin{array}{c}\text { Days to onset } \\
\text { of } \\
\text { deterioration }\end{array}$ & $\begin{array}{c}\text { Vase } \\
\text { life } \\
\text { (days })\end{array}$ \\
\hline $\begin{array}{l}\text { Control }\left(\mathrm{A}_{0}\right) \\
\mathrm{A}_{1}(0.25)\end{array}$ & $41.18 \mathrm{c}$ & $55.56 \mathrm{a}$ & $1.36 \mathrm{a}$ & $5.9 \mathrm{~b}$ & 7.00 \\
$\mathrm{~A}_{2}(0.50)$ & $55.41 \mathrm{c}$ & $52.59 \mathrm{ab}$ & $1.14 \mathrm{~b}$ & $6.1 \mathrm{ab}$ & 7.22 \\
$\mathrm{~A}_{3}(0.75)$ & $61.90 \mathrm{a}$ & $50.34 \mathrm{bc}$ & $0.94 \mathrm{~cd}$ & $6.5 \mathrm{ab}$ & 7.78 \\
$\mathrm{~A}_{4}(1.00)$ & $45.69 \mathrm{c}$ & $48.48 \mathrm{bc}$ & $0.80 \mathrm{~d}$ & $7.4 \mathrm{a}$ & 9.11 \\
\hline $\begin{array}{l}\text { Level of } \\
\text { significance }\end{array}$ & $* *$ & $* *$ & $7.1 \mathrm{ab}$ & 8.67 \\
\hline $\mathrm{CV}(\%)$ & 5.11 & 4.54 & $* *$ & $\mathrm{~ns}$ \\
\hline
\end{tabular}

Means in the same column followed by different letters are significantly different by DMRT. ** indicates significant at $1 \%$ level and ' $n s$ ' indicates non-significant

\section{Interaction effect of sucrose and aluminium sulphate}

\section{Water uptake}

Interaction of sucrose and $\mathrm{Al}_{2}\left(\mathrm{SO}_{4}\right)_{3}$ had significant influence on water uptake (Table 3). The scapes held in distilled water (without sucrose and $\mathrm{Al}_{2}\left(\mathrm{SO}_{4}\right)_{3}$ ) recorded a lower water uptake $(39.80 \mathrm{~g})$. On the other hand, the scapes held in the vase solution containing $4 \%$ sucrose and $0.75 \mathrm{mM} \mathrm{Al}_{2}\left(\mathrm{SO}_{4}\right)_{3}$ had the highest water uptake $(76.60 \mathrm{~g})$, closely followed by those held in $4 \%$ sucrose and 0.50 $\mathrm{mM} \mathrm{Al} 2\left(\mathrm{SO}_{4}\right)_{3}$ vase solution $(65.77 \mathrm{~g})$. This result is in full agreement with the findings of Gowda and Gowda, (1990) in gladiolus and Mukhopadhyay (1982) in cut tuberose.

\section{Transpiration loss of water}

Interaction of sucrose and aluminium sulphate affected significantly the water loss by transpiration of the scape kept in vase solution (Table 3). The maximum 
water loss $(67.83 \mathrm{~g})$ was observed in vase solution containing distilled water (control) and the minimum water loss $(36.83 \mathrm{~g}$ ) was found in solution containing $4 \%$ sucrose and $0.75 \mathrm{mM} \mathrm{Al}\left(\mathrm{SO}_{4}\right)_{3}$. It is clear from the above results that different concentrations of sucrose and $\mathrm{Al}_{2}\left(\mathrm{SO}_{4}\right)_{3}$ proved effective in increasing the water uptake and enhancing vase life and decreasing water loss when these solutions were used singly. But in combination their solutions were found more effective in maintaining an increased pattern of water uptake and decreasing water loss by transpiration.

\section{Transpiration loss and water uptake ratio}

Interaction of sucrose and $\mathrm{Al}_{2}\left(\mathrm{SO}_{4}\right)_{3}$ significantly influenced the ratio of transpiration loss and water uptake (Table 3 ). The scapes which recorded the highest water uptake, held in sucrose $4 \%$ with $0.75 \mathrm{mM} \mathrm{Al}_{2}\left(\mathrm{SO}_{4}\right)_{3}$ had the lowest ratio (0.48), while those held in distilled water only had the highest ratio (1.71). Solutions of sucrose and $\mathrm{Al}_{2}\left(\mathrm{SO}_{4}\right)_{3}$ alone and in combination were found effective in maintaining a decrease in the ratio of transpiration loss and water uptake in the present study were also supported by Shobha and Gowda (1994) in cut calendula flowers.

\section{Days to onset of deterioration}

The interaction effect of sucrose and aluminium sulphate had significant effect on days to onset of deterioration (Table 3). The maximum days (8.0) was taken for starting of deterioration of cut Hippeastrum flower by the combination of $4 \%$ sucrose and $0.75 \mathrm{mM} \mathrm{Al}_{2}\left(\mathrm{SO}_{4}\right)_{3}$, which was closely followed by 7.7 days at $2 \%$ sucrose and $0.75 \mathrm{mM} \mathrm{Al}_{2}\left(\mathrm{SO}_{4}\right)_{3}$. The minimum days for starting the deterioration of flower (5.8 days) in control. Similar results were found by Shobha and Gowda (1994) in calendula flowers who observed that the relative contribution of the petals to the large accumulation of $0.75 \mathrm{mM} \mathrm{Al} 2\left(\mathrm{SO}_{4}\right)_{3}$ and sucrose resulted in extending the longevity of the shoots with flowers.

\section{Vase life}

The vase life of floral scape was varied significantly by the combined effect of sucrose and aluminium sulphate (Table 3). The scapes held in a solution with $4 \%$ sucrose and $0.75 \mathrm{mM} \mathrm{Al}_{2}\left(\mathrm{SO}_{4}\right)_{3}$ had the maximum vase life (10.33 days), while those held in a solution without sucrose and aluminium sulphate had the minimum vase life (7 days). Solution of sucrose and $\mathrm{Al}_{2}\left(\mathrm{SO}_{4}\right)_{3}$ in combination were found effective in extending the vase life of cut flowers. This might be due to a synergistic effect of sucrose and $\mathrm{Al}_{2}\left(\mathrm{SO}_{4}\right)_{3}$ which improved water balance and osmotic potential, since sugar had been observed to reduce moisture stress in cut flowers by affecting stomatal closure, preventing transportation and water loss. The findings of the present study are further supported by Gowda and 
Gowda, (1990) in gladiolus, Mukhopadhyay (1982) in tuberose and Gowda (1990) in tuberose.

Table 3. Interaction effect of sucrose and aluminium sulphate on post-harvest physiology and quality of Hippeastrum flower

\begin{tabular}{|c|c|c|c|c|c|}
\hline Treatment & $\begin{array}{c}\text { Total water } \\
\text { uptake in } 10 \\
\text { days }(\mathrm{g} / \mathrm{scape})\end{array}$ & $\begin{array}{c}\text { Transpiration } \\
\text { loss in } 10 \text { days } \\
\text { (g/scape) }\end{array}$ & $\begin{array}{c}\text { Transpiration } \\
\text { loss and water } \\
\text { uptake ratio }\end{array}$ & $\begin{array}{c}\text { Days to onset } \\
\text { of } \\
\text { deterioration }\end{array}$ & $\begin{array}{c}\text { Vase life } \\
\text { (days) }\end{array}$ \\
\hline $\mathrm{S}_{0} \times \mathrm{A}_{0}$ & $39.80 \mathrm{f}$ & $67.83 \mathrm{a}$ & $1.71 \mathrm{a}$ & $5.8 \mathrm{~cd}$ & $7.00 \mathrm{c}$ \\
\hline $\mathrm{S}_{0} \times \mathrm{A}_{1}$ & 46.00 ef & $62.13 \mathrm{~b}$ & $1.36 \mathrm{~b}$ & $6.3 \mathrm{a}-\mathrm{c}$ & $8.00 \mathrm{bc}$ \\
\hline $\mathrm{S}_{0} \times \mathrm{A}_{2}$ & $46.43 \mathrm{ef}$ & $58.50 \mathrm{bc}$ & $1.26 \mathrm{bc}$ & $7.0 \mathrm{a}-\mathrm{c}$ & 8.70 a-c \\
\hline $\mathrm{S}_{0} \times \mathrm{A}_{3}$ & 53.00 cde & $58.20 \mathrm{bc}$ & $1.10 \mathrm{~cd}$ & $7.5 \mathrm{a}-\mathrm{c}$ & $9.33 \mathrm{ab}$ \\
\hline $\mathrm{S}_{0} \times \mathrm{A}_{4}$ & $40.27 \mathrm{f}$ & $55.63 \mathrm{~cd}$ & $1.39 \mathrm{~b}$ & $6.4 \mathrm{a}-\mathrm{c}$ & 8.65 a-c \\
\hline $\mathrm{S}_{1} \times \mathrm{A}_{0}$ & $41.50 \mathrm{f}$ & $54.93 \mathrm{~cd}$ & $1.33 \mathrm{~b}$ & 6.0 a-d & 8.00 a-c \\
\hline$S_{1} \times A_{1}$ & 46.07 ef & $51.80 \mathrm{de}$ & $1.12 \mathrm{~cd}$ & $6.7 \mathrm{a}-\mathrm{c}$ & 8.67 a-c \\
\hline $\mathrm{S}_{1} \times \mathrm{A}_{2}$ & $54.43 \mathrm{~cd}$ & 49.07 ef & $0.90 \mathrm{fg}$ & $6.8 \mathrm{a}-\mathrm{c}$ & $8.68 \mathrm{bc}$ \\
\hline $\mathrm{S}_{1} \times \mathrm{A}_{3}$ & $56.10 \mathrm{c}$ & $46.30 \mathrm{fg}$ & $0.83 \mathrm{gh}$ & $7.7 \mathrm{ab}$ & $9.53 \mathrm{ab}$ \\
\hline $\mathrm{S}_{1} \times \mathrm{A}_{4}$ & $43.17 \mathrm{f}$ & $46.50 \mathrm{fg}$ & $1.08 \mathrm{de}$ & 6.0 a-d & 8.00 a-c \\
\hline $\mathrm{S}_{2} \times \mathrm{A}_{0}$ & $42.23 \mathrm{f}$ & $43.90 \mathrm{~g}$ & $1.04 \mathrm{def}$ & $6.6 \mathrm{~d}$ & 8.80 a-c \\
\hline $\mathrm{S}_{2} \times \mathrm{A}_{1}$ & $47.17 \mathrm{def}$ & $43.83 \mathrm{~g}$ & $0.93 \mathrm{efg}$ & $6.3 \mathrm{~cd}$ & $8.00 \mathrm{bc}$ \\
\hline $\mathrm{S}_{2} \times \mathrm{A}_{2}$ & $65.77 \mathrm{~b}$ & $43.47 \mathrm{~g}$ & $0.66 \mathrm{~h}$ & $6.7 \mathrm{a}-\mathrm{c}$ & $8.64 \mathrm{bc}$ \\
\hline $\mathrm{S}_{2} \times \mathrm{A}_{3}$ & $76.60 \mathrm{a}$ & $36.83 \mathrm{~h}$ & $0.48 \mathrm{i}$ & $8.0 \mathrm{a}$ & $10.33 \mathrm{a}$ \\
\hline $\mathrm{S}_{2} \times \mathrm{A}_{4}$ & $53.63 \mathrm{cde}$ & $43.30 \mathrm{~g}$ & $0.81 \mathrm{gh}$ & $6.7 \mathrm{~b}-\mathrm{d}$ & $8.67 \mathrm{a}-\mathrm{c}$ \\
\hline $\begin{array}{c}\text { Level of } \\
\text { significance }\end{array}$ & $* *$ & $* *$ & $* *$ & $*$ & $* *$ \\
\hline $\mathrm{CV}(\%)$ & 5.11 & 4.54 & 7.57 & 16.53 & 14.54 \\
\hline
\end{tabular}

Means in the same column followed by different letters are significantly different by DMRT. ** indicates significant at $1 \%$ level * indicates significant at $5 \%$ level.

$\mathrm{S}_{0}=0 \%$ Sucrose (distilled water)

$\mathrm{S}_{1}=2 \%$ Sucrose

$\mathrm{S}_{2}=4 \%$ Sucrose
$\mathrm{A}_{0}=0 \mathrm{mM}$ aluminium sulphate (distilled water)

$\mathrm{A}_{1}=0.25 \mathrm{mM}$ aluminium sulphate

$\mathrm{A}_{2}=0.50 \mathrm{mM}$ aluminium sulphate

$\mathrm{A}_{3}=0.75 \mathrm{mM}$ aluminium sulphate

$\mathrm{A}_{4}=1.0 \mathrm{mM}$ aluminium sulphate

\section{Fresh weight}

The fresh weight of floral scape on any observation day during the vase life period was not affected by sucrose (Fig. 1) but was affected by aluminium sulphate (Fig. 2). The scape held in $2 \%$ sucrose showed the maximum increase in weight (84.19 g) at $4^{\text {th }}$ day after setting the trial, while those held in solutions without sucrose showed the minimum weight per scape $(80.32 \mathrm{~g})$ at the same day. 
Aluminium sulphate had significant effect on fresh weight of flower scape at $6^{\text {th }}$ and $10^{\text {th }}$ days of vase life (Fig. 2). The scapes held in $0.75 \mathrm{mM} \mathrm{Al}_{2}\left(\mathrm{SO}_{4}\right)_{3}$ solution showed the highest increment of weight on every observation day during the vase period. The maximum fresh weight $(93.28 \mathrm{~g})$ was obtained at $4^{\text {th }}$ day of the observation trial and it was gradually decreased at $6^{\text {th }}$ and $10^{\text {th }}$ day of vase life.

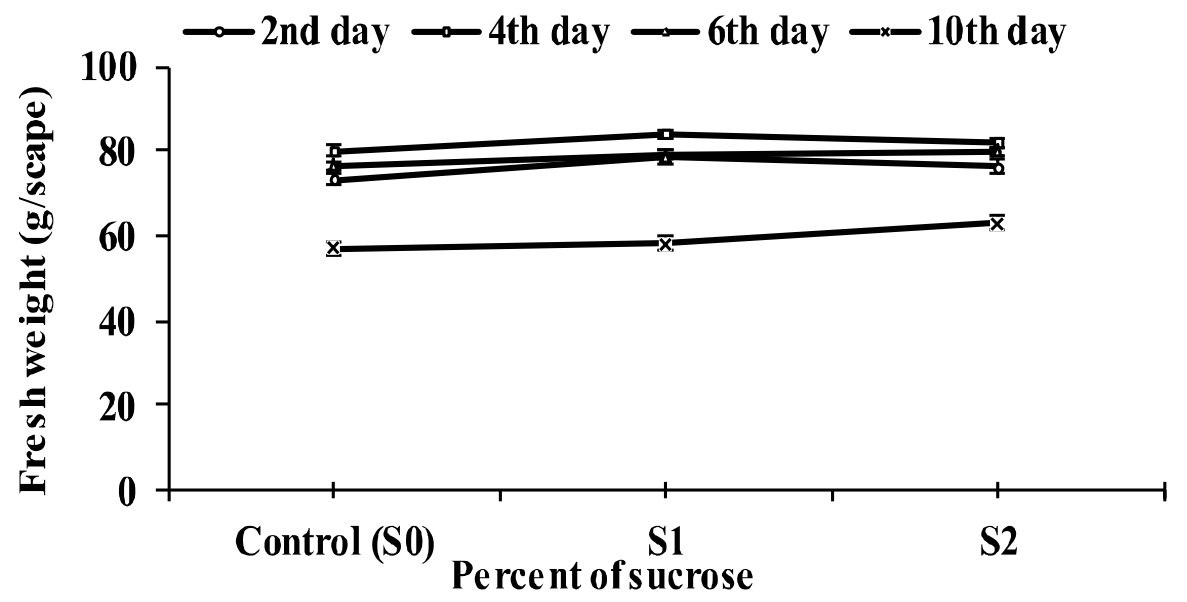

Fig.1. Effect of different conc. of sucrose on fresh weight of Hippeastrum cut flower at different days of vase life.

$\mathrm{S}_{0}=0 \%$ sucrose, $\mathrm{S}_{1}=2 \%$ sucrose and $\mathrm{S}_{2}=4 \%$ sucrose

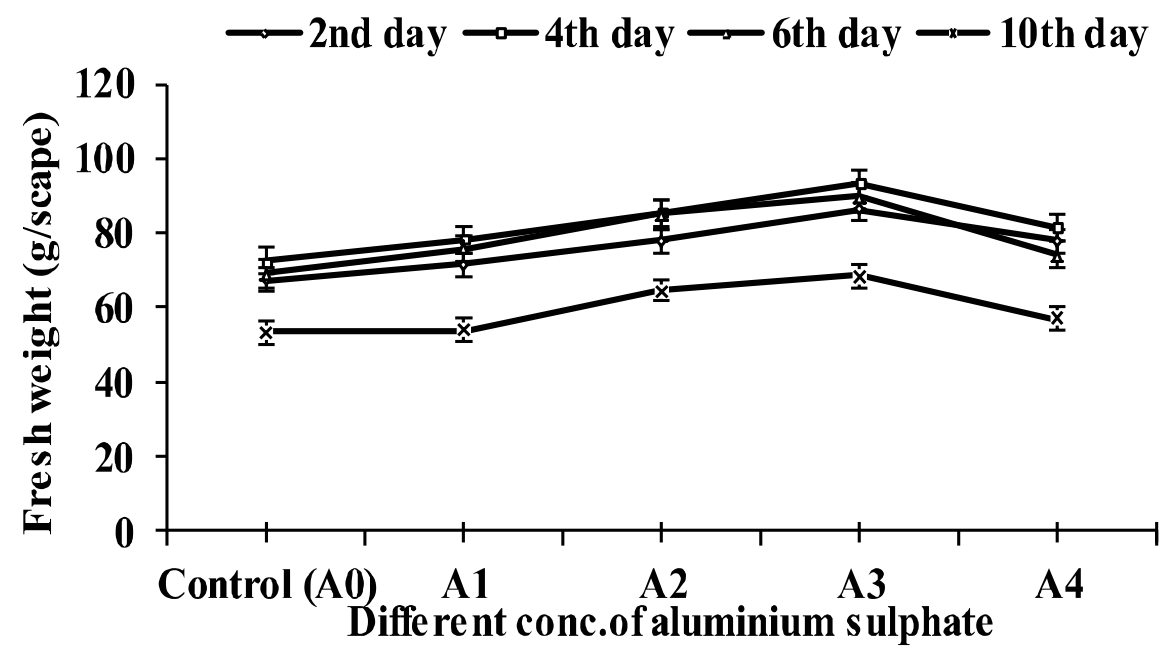

Fig.2. Effect of different conc. of aluminium sulphate on fresh weight of Hippeastrum cut flower at different days of vase life.

$\mathrm{A}_{0}=0 \mathrm{mM} \mathrm{Al}_{2}\left(\mathrm{SO}_{4}\right)_{3}, \mathrm{~A}_{1}=0.25 \mathrm{mM} \mathrm{Al}_{2}\left(\mathrm{SO}_{4}\right)_{3}, \mathrm{~A}_{2}=0.50 \mathrm{mM} \mathrm{Al}\left(\mathrm{SO}_{4}\right)_{3}, \mathrm{~A}_{3}=$ $0.75 \mathrm{mM} \mathrm{Al}_{2}\left(\mathrm{SO}_{4}\right)_{3}, \mathrm{~A}_{4}=1.0 \mathrm{mM} \mathrm{Al} 2\left(\mathrm{SO}_{4}\right)_{3}$ 
Table 4. Interaction effect of sucrose and aluminium sulphate on fresh weight of Hippeastrum flower scape at different days in vase solution

\begin{tabular}{c|c|c|c|c|c}
\hline \multirow{2}{*}{ Treatment } & \multicolumn{5}{|c}{ Average fresh weight $(\mathrm{g} / \mathrm{scape})$} \\
\cline { 2 - 6 } & $1^{\text {st }}$ day & $2^{\text {nd }}$ day & $4^{\text {th }}$ day & $6^{\text {th }}$ day & $10^{\text {th }}$ day \\
\hline $\mathrm{S}_{0} \times \mathrm{A}_{0}$ & 55.70 & 62.80 & 68.80 & $66.03 \mathrm{~b}$ & $49.93 \mathrm{cde}$ \\
$\mathrm{S}_{0} \times \mathrm{A}_{1}$ & 71.53 & 76.80 & 86.23 & $82.00 \mathrm{ab}$ & $60.43 \mathrm{~b}-\mathrm{e}$ \\
$\mathrm{S}_{0} \times \mathrm{A}_{2}$ & 71.47 & 77.33 & 87.27 & $89.57 \mathrm{ab}$ & $68.17 \mathrm{ab}$ \\
$\mathrm{S}_{0} \times \mathrm{A}_{3}$ & 76.13 & 82.20 & 87.50 & $82.57 \mathrm{ab}$ & $62.00 \mathrm{bcd}$ \\
$\mathrm{S}_{0} \times \mathrm{A}_{4}$ & 62.10 & 68.23 & 71.80 & $64.07 \mathrm{~b}$ & $45.27 \mathrm{e}$ \\
$\mathrm{S}_{1} \times \mathrm{A}_{0}$ & 61.43 & 70.43 & 74.50 & $72.10 \mathrm{ab}$ & $56.10 \mathrm{~b}-\mathrm{e}$ \\
$\mathrm{S}_{1} \times \mathrm{A}_{1}$ & 64.87 & 69.37 & 73.60 & $68.50 \mathrm{ab}$ & $46.97 \mathrm{de}$ \\
$\mathrm{S}_{1} \times \mathrm{A}_{2}$ & 73.33 & 80.47 & 88.73 & $88.27 \mathrm{ab}$ & $64.97 \mathrm{bc}$ \\
$\mathrm{S}_{1} \times \mathrm{A}_{3}$ & 81.47 & 88.40 & 96.07 & $89.70 \mathrm{ab}$ & $62.17 \mathrm{bcd}$ \\
$\mathrm{S}_{1} \times \mathrm{A}_{4}$ & 78.50 & 84.93 & 88.03 & $77.90 \mathrm{ab}$ & $60.90 \mathrm{~b}-\mathrm{e}$ \\
$\mathrm{S}_{2} \times \mathrm{A}_{0}$ & 60.80 & 68.47 & 74.63 & $69.60 \mathrm{ab}$ & $54.13 \mathrm{~b}-\mathrm{e}$ \\
$\mathrm{S}_{2} \times \mathrm{A}_{1}$ & 62.93 & 68.93 & 74.90 & $77.17 \mathrm{ab}$ & $54.50 \mathrm{~b}-\mathrm{e}$ \\
$\mathrm{S}_{2} \times \mathrm{A}_{2}$ & 70.83 & 75.97 & 80.60 & $77.37 \mathrm{ab}$ & $60.93 \mathrm{~b}-\mathrm{e}$ \\
$\mathrm{S}_{2} \times \mathrm{A}_{3}$ & 80.53 & 88.83 & 96.27 & $96.80 \mathrm{a}$ & $80.80 \mathrm{a}$ \\
$\mathrm{S}_{2} \times \mathrm{A}_{4}$ & 73.47 & 80.53 & 84.77 & $80.37 \mathrm{ab}$ & $65.13 \mathrm{bc}$ \\
\hline Level of $_{\text {significance }}$ & & $\mathrm{ns}$ & $\mathrm{ns}$ & & \\
\hline $\mathrm{CV} \%)$ & 14.04 & 13.34 & 12.66 & 13.02 \\
\hline
\end{tabular}

Means in the same column followed by different letters are significantly different by DMRT. ** indicates significant at $1 \%$ level and ' $n s$ ' indicates non-significant.

$$
\begin{array}{lll}
\mathrm{S}_{0}=0 \% \text { sucrose } & \mathrm{A}_{0}=0 \mathrm{mM} \mathrm{Al}\left(\mathrm{SO}_{4}\right)_{3} & \mathrm{~A}_{3}=0.75 \mathrm{mM} \mathrm{Al}_{2}\left(\mathrm{SO}_{4}\right)_{3} \\
\mathrm{~S}_{1}=2 \% \text { sucrose and } & \mathrm{A}_{1}=0.25 \mathrm{mM} \mathrm{Al}{ }_{2}\left(\mathrm{SO}_{4}\right)_{3} & \mathrm{~A}_{4}=1.0 \mathrm{mM} \mathrm{Al}{ }_{2}\left(\mathrm{SO}_{4}\right)_{3} \\
\mathrm{~S}_{2}=4 \% \text { sucrose } & \mathrm{A}_{2}=0.50 \mathrm{mM} \mathrm{Al}_{2}\left(\mathrm{SO}_{4}\right)_{3} &
\end{array}
$$

The interaction effect of sucrose and $\mathrm{Al}_{2}\left(\mathrm{SO}_{4}\right)_{3}$ had significant influence on the fresh weight of floral scapes at $6^{\text {th }}$ and $10^{\text {th }}$ day of vase life but no significant effect on fresh weight at $2^{\text {nd }}$ and $4^{\text {th }}$ day of vase life (Table 4$)$. The scapes held in vase solutions without sucrose and $\mathrm{Al}_{2}\left(\mathrm{SO}_{4}\right)_{3}$ had lower fresh weight on any day of vase life, while those held in the solution containing $4 \%$ sucrose and $0.75 \mathrm{mM}$ $\mathrm{Al}_{2}\left(\mathrm{SO}_{4}\right)_{3}$ showed a weight increment of about 10 per cent over the initial weight on the $4^{\text {th }}$ day of vase life. The scapes held in distilled water were increased in fresh weight slightly, but about $9.55 \%$ over the original weight, which then declined compared to the original weight after the $4^{\text {th }}$ day of vase life. The scapes held in $4 \%$ sucrose and $0.75 \mathrm{mM} \mathrm{Al}_{2}\left(\mathrm{SO}_{4}\right)_{3}$ maintained their fresh weight well 
above the original weight even up to the $10^{\text {th }}$ day of vase life. Floral scapes held in $4 \%$ sucrose and $0.75 \mathrm{mM} \mathrm{Al} 2\left(\mathrm{SO}_{4}\right)_{3}$ vase solution maintained their fresh weight above initial weights even on the $6^{\text {th }}$ day of vase life, while those held in distilled water lost their fresh weight gains in comparison with their initial weight on the $6^{\text {th }}$ day. These results indicated that $\mathrm{Al}_{2}\left(\mathrm{SO}_{4}\right)_{3}$ helps flower scape maintain their fresh weight. The results of the experiment supports other published reports that $\mathrm{Al}_{2}\left(\mathrm{SO}_{4}\right)_{3}$ and sucrose increased cut flower life, by increasing the water uptake and maintaining higher fresh weight of cut gladiolus and calendula flowers (Gowda and Murthy, 1994; Shobha and Gowda, 1994).

\section{Relationship between water uptake and vase life of flowers.}

There exhibited a linear relationship between vase life of cut Hippeastrum flowers and water uptake as indicated by the following equation: $y=0.056 x+$ 5.791, $\left(\mathrm{R}^{2}=0.5433\right)$. The regression line stated that the vase life of hippeastrum flower increased at the rate of 0.056 day for per unit change of water uptake. The $\mathrm{R}^{2}$ value indicated that $54.33 \%$ vase life of Hippeastrum cut flower was due to water uptake.

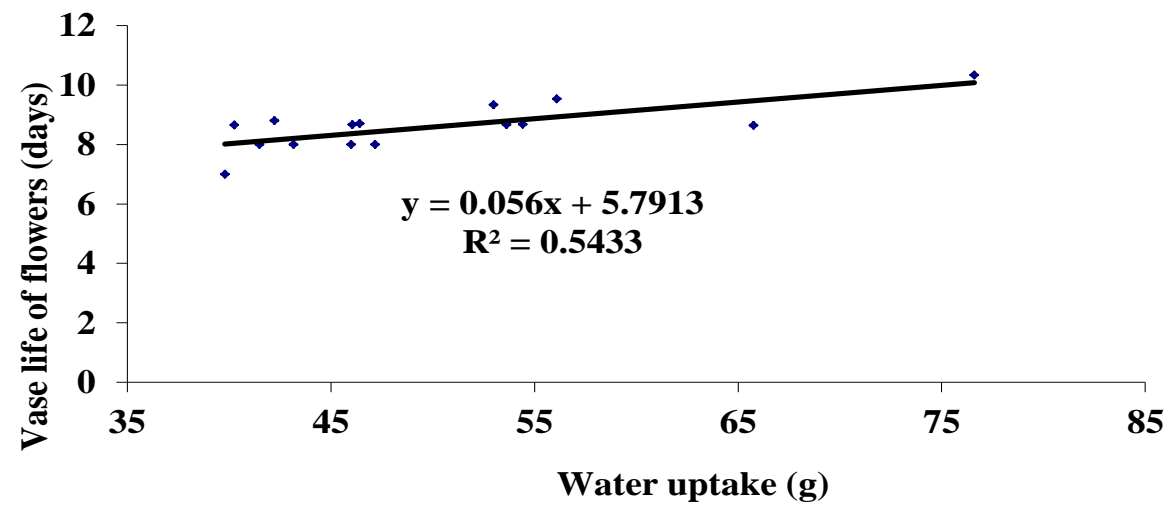

Fig. 3. Relationship between water uptake and vase life of Hippeastrum cut flower.

\section{Conclusion}

The results of the present experiment suggests that vase solution containing $4 \%$ sucrose and $0.75 \mathrm{mM}$ aluminium sulphate can be used for prolonging the vase life of cut Hippeastrum flower cv. Apple Blossom. 


\section{References}

Anserwadekar, K.W. and V.K. Patil. 1986. Vase life studies of gladiolus ( $G$. grandiflorus) cv. H.B. Pitt. Acta Horticulturae, 171: 279-283.

Bhattacharjee, S. K. and L. C. Dey. 2010. Bulbous ornamentals for pot culture. In: Advanced Commercial Floriculture. $2^{\text {nd }}$ ed. Vol. 2. Aavishkar Publishers, Jaipur 302003 (Rajasthan), India. Pp. 591-643.

Datta, S. K., V. N. Gupta and B. K. Banergee. 2008. Hippeastrum: An excellent bulbous plants at National Botanical Research. BVAAP. 16(1): 36-46.

De, L. C. and S. K. Bhattacharjee. 2006. Post-harvest handling of cut flowers and loose flowers. In: Advances in Ornamental Horticulture. Vol. 5. (Ed.). S. K. Bhattacharjee, Pointer Publishers, Vyas Building, S. M. S. Highway, Jaipur, 302003 (Raj), India, Pp. 120-169.

Farhat, M. M., N. G. A., Abd-Aziz, Kh. I. Hashish and A. Gaber. 2014. Post-harvest physiology and vase life of rose (Rosa hybrid L. cv. Grand Prix) cut flowers as influenced by using sucrose and some chemical treatments. Middle East J. Agric. Res. 3(4): 815-819.

Garibaldi, E. A. and F. Dembrogio. 1989. Preserving cut gladiolus flowers. Colture protette. 18(6): 33-35.

Gomez, K. A. and A. A. Gomez. 1984. Statistical Procedures for Agricultural Research ( $2^{\text {nd }}$ edition). Int. Rice Res. Inst. John Wiley and Sons publication, New York. Pp. 28-192.

Goszczynska, D.M., T.R. Pisulewsk and R.M. Rudnicki. 1989. Postharvest studies with Daffodil flowers. Prace Instytutu Sadownictwa Kwiaciarstwa Skierniewicach. Seria, Rosliny Ozdobne. 14: 147-154.

Gowda, J. V. N. 1986. Post- harvest life of china aster as influenced by chemical preservations. Curr. Sci. 15(12): 138-139.

Gowda, J. V. N. 1990. Effect of sucrose and aluminium sulphate on the post harvest life of tuberose double. Curr. Res. U.A. S. Bangalore. 19(1): 14-16.

Gowda, J. V. N. and G. M. A. Murthy. 1994. Effect of aluminium, calcium and sucrose on post-harvest life of gladiolus. In: Floriculture Technology, Trades and Trends. (Eds). J. Prakash and K. R. Bhandary, Oxford and IBH Publishing Co. Pvt. Ltd. Calcutta. Pp. 492-495.

Gowda, J. V. N. and V. N. Gowda. 1990. Effect of calcium, aluminum and sucrose on vase life of Gladiolus. Crop Res. Hisar. 3(1): 105-106.

Gupta, A. K., B. S. Reddy and K. Singh. 1994. Post- harvest physiology of cut gladiolus cv. sylvia as affected by cobalt and sucrose. In: Floriculture Technology, Trades and Trends. (Eds). J. Prakash and K. R. Bhandary, Oxford and IBH Publishing Co. Pvt. Ltd. Calcutta. Pp. 513-518.

Halvey, A. H. and S. Mayak. 1981. Senescence and post-harvest physiology of cut flowers, part 2. Hort. Rev. 3: 59-143. 
Ichimura, K. and S. Ueyma. 1998. Effects of temperature and application of aluminium sulphate on the post-harvest life of cut rose flowers. Bull. National Res. Inst. Veg. Ornamental Plant \& Tea. 13: 51-60.

Ichimura, K., Y. Kawabata, M. Kishimoto, R. Goto and K. Yemada. 2003. Shortage of soluble carbohydrates is largely responsible for short vase life of cut 'Sonia' rose flowers. J. Japan Soc. Hort. Sci. 72: 292-298.

Jana, B. K. 1979. Hippeastrum- The export potential bulbous plant. Lal-bough J. 24: 1720.

Khondakar, S. R. K. and B. C. Mojumder. 1985. Studies on prolonging the vase life of tuberose cut flowers. South Indian Hort. 33(2): 145-147.

Mukhopadhyay, T. P. 1982. Effect of chemicals on floral development and vase life of tuberose (Polianthes tuberosa) var. 'Single'. South Indian Hort. 30(4): 281-284.

Pathak, S., M. A. Choudhury and S. K. Chatterjee. 1979. Effects of some germicides, hormones and sugars on longevity and keeping quality of tuberose. Indian J. Hort. 31: $95-96$

Reddy, B. K., A. K. Gupta and K. Singh. 1994. Physiological role of 8-hydroxyquinoline sulphate and sucrose in the post-harvest physiology of gladiolus cv. sylvia. In: Floriculture Technology, Trades and Trends. (Eds). J. Prakash and K. R. Bhandary, Oxford and IBH Publishing Co. Pvt. Ltd. Calcutta. Pp. 496-502.

Reddy, B. S. and K. Singh. 1997. Gerbera. Karnatka J. Agric. Sci. 10: 1049-1054.

Rogers, M. N. 1973. A historical and critical review of post-harvest physiology research on cut flowers . Hort. Sci. 8: 189-194.

Shobha, K. S. and J. V. N. Gowda. 1994. Effect of pulsing and aluminium sulphate on vase life of cut calendula flowers. In: Floriculture Technology, Trades and Trends. (Eds). J. Prakash and K. R. Bhandary, Oxford and IBH Publishing Co. Pvt. Ltd. Calcutta. Pp. 566-569.

Singh, K., B. S. Reddy and A. K. Gupta. 1994. Role of gibberellic acid, 8hydroxyquinoline sulphate and sucrose in extending post-harvest vase life of tuberose flowers cv. double. In: Floriculture Technology, Trades and Trends. (Eds). J. Prakash and K. R. Bhandary, Oxford and IBH Publishing Co. Pvt. Ltd. Calcutta. Pp. 519-524. 